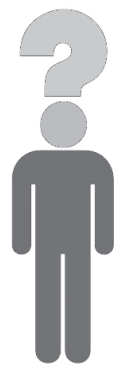

Paweł Kaszowski

\title{
O ODPOWIEDZIALNOŚCI PŁYNĄCEJ Z FUNKCJONOWANIA ELEKTROWNI JĄDROWEJ
}

Odkąd powstał pomysł budowy elektrowni jądrowej w Polsce, rozgorzała dyskusja na temat bezpieczeństwa związanego z funkcjonowaniem takiego obiektu. Społeczności lokalne żyjące w miejscach przewidzianych pod budowę elektrowni mają różnorodne zdanie na ten temat. Zawiązują się komitety przeciwko budowie elektrowni jądrowej, jak również opozycyjne stowarzyszenia. Taki obraz rzeczywistości uświadamia nam, że nasze społeczeństwo jest niedoinformowane w sprawach związanych z budową, zasadą działania i pracy takiej elektrowni. Artykuł opisuje budowę, zasadę działania elektrowni jądrowej oraz wiążące się z jej pracą zagrożenia. Omawia również problemy związane z bezpieczeństwem funkcjonowania elektrowni jądrowej i odpowiedzialności z tym związanej.

Od rozszczepienia do elektryczności, czyli jak działa elektrownia jądrowa

Wszystko zaczęło się od Alberta Einsteina, który w 1905 roku opublikował szczególną teorię względności. Okazało się, że masę można zamienić w energię, a energię w masę. Zależność tę opisuję słynny wzór ${ }^{1}$ :

$$
\begin{aligned}
E=m c^{2}, & \text { gdzie: } \\
& E-\text { energia, } \\
& m-\text { masa, } \\
& c-\text { prędkość światła. }
\end{aligned}
$$

$1 \quad$ Ł. Koszuk, Albert Einstein i równanie $E=m c^{2}$, „Forum Atomowe” 2 (2013), s. 5. 
Wywołało to wielkie zaskoczenie, a jednocześnie pokazało, jak duża energia może tkwić w małej masie, jaką ma jądro atomu. Decyduje o tym czynnik c ${ }^{2}$, czyli prędkość światła podniesiona do kwadratu. Jedynym problemem był sposób, w jaki tę giagantyczną energię można uwolnić. Dokonali tego Otto Hahn i Fritz Strassman z pomocą Lisy Meitner - przeprowadzili oni pierwszą reakcję rozszczepienia i przewidzieli wyzwolenie dodatkowych neutronów $w$ trakcie rozpadu promieniotwórczego. Pozostaje jednak pytanie, gdzie faktycznie tkwi ta energia. Jeżeli wyobrazimy sobie wagę szalkową i położymy na jednej szalce jądro atomu helu - czyli dwa protony i dwa neutrony związane ze sobą - a na drugiej szalce taką samą liczbę niezwiązanych protonów i neutronów, okaże się, że te swobodne ważą więcej niż związane w jądro atomowe helu. Sytuację tę ukazuje Rysunek 1. Okazuje się, że część masy nukleonów została zamieniona na energię zmagazynowaną w wiązaniach pomiędzy nukleonami. Jeżeli rozerwiemy jądro atomu, wyzwoli się energia, która wcześniej scalała go w jeden obiekt.

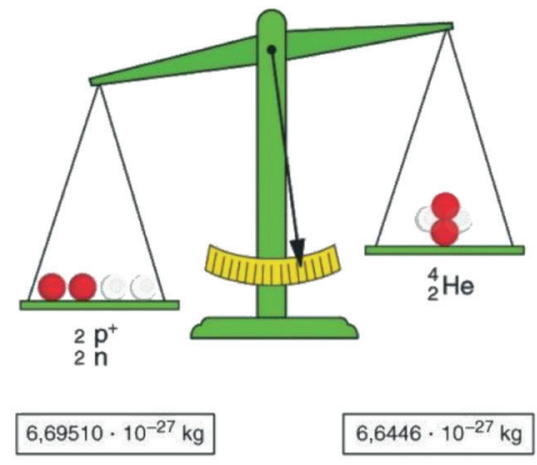

Rysunek 1. Różnica masy pomiędzy związanym jądrem helu a nukleonami budującymi jego jądro. Żródło: materiały własne, Fundacja Forum Atomowe.

Jądra niektórych pierwiastków, jak na przykład uranu, rozszczepiają się w sposób spontaniczny, samoczynnie. Prawdopodobieństwo wystąpienia takiej reakcji jest jednak bardzo niskie. Dlatego aby mieć pewność, że reakcja rozszczepienia wystąpi, uderzamy w jądra neutronami. Podczas takiej reakcji neutron zostaje pochłonięty przez jądro uranu (Rysunek 2), rozszczepiając je na dwa fragmenty o mniej więcej równych masach. W trakcie reakcji rozszczepienia powstają średnio dwa lub trzy nowe neutrony oraz wydziela się energia około 200 milionów elektronowoltów. Czy to dużo, czy mało energii? 


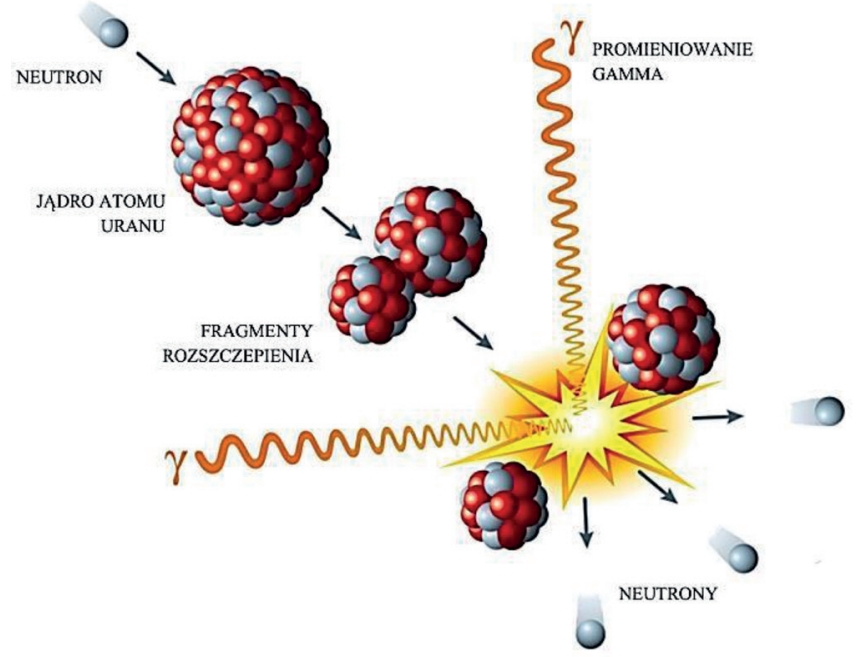

Rysunek 2. Przykładowa reakcja rozszczepienia jądra uranu.

Źródło: www.energiajadrowa.pl/wp-content/uploads/2014/01/rozszczepienie.jpg (15.12.2014).
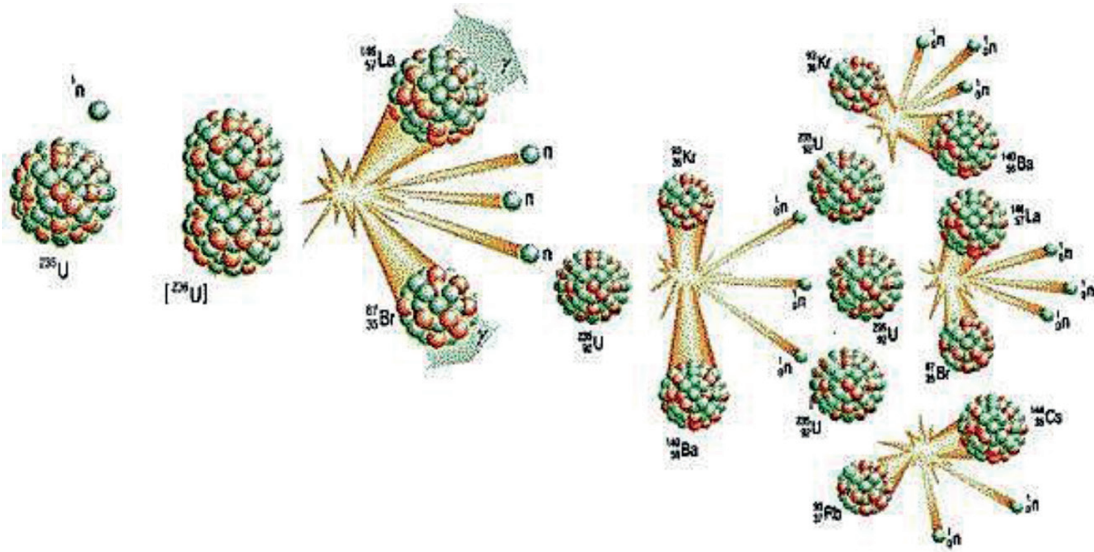

Rysunek 3. Reakcja łańcuchowa rozszczepienia jądra uranu U-235.

Źródło: www.atomki.nuclear.pl/images/reakcja.jpg (15.12.2014). 
Elektronowolt to jednostka bardzo mała. Stosują ją między innymi fizycy jądrowi, czyli badający zjawiska zachodzące w przestrzeni subatomowej. Jeden elektronowolt to bardzo mała energia, równa energii kinetycznej elektronu przyspieszonego różnicą potencjałów jednego wolta. Dla porównania energia wydzielona w trakcie procesu spalania jednego atomu węgla to około 4 elektronowolty, czyli 50 milionów razy mniej niż powstaje w podczas rozszczepieniu jednego jądra uranu. Dla porównania, aby wytworzyć taką samą ilość energii, elektrownia jądrowa potrzebuje rocznie takiej ilości paliwa jądrowego, która mieści się na naczepie jednego samochodu ciężarowego, a elektrownia węglowa potrzebuje dziennie kilka składów pociągu załadowanych węglem.

Podczas jednej reakcji rozszczepienia powstaje za mało energii, aby napędzić turbiny parowe. Dlatego potrzeba szeregu reakcji następujących po sobie. Neutrony, które powstają w wyniku pojedyńczego rozszczepienia, powodują kolejne, i tak dzięki rozszczepieniu jednego atomu rozszczepieniu ulegają kolejne trzy atomy. Tworzy się reakcja, którą naznazywamy łańcuchową. Schemat reakcji łańcuchowej przedstawia Rysunek 3. W przeciwieństwie do bomby atomowej w reaktorze jądrowym reakcja łańcuchowa jest kontrolowana. Nie ma możliwości, aby reaktor wybuchł jak bomba. Aby do wybuchu nigdy nie doszło, czuwają prawa fizyki. Przede wszystkim wzbogacenie uranu w odpowiedni izotop, U-235, jest za małe, żeby reakcja rozwijała się w sposób niekontrolowany. W reaktorze elektrowni jądrowej wzbogacenie wynosi około 3-5 proc., w badawczym - około 20 proc., natomiast bombę potrzebujemy wzbogacić w uran U-235 o ponad 90 proc.!

Reakcja łańcuchowa jest kontrolowana za pomocą prętów sterujących, które mogą zanurzać się w rdzeniu reaktora pomiędzy prętami paliwowymi zawierającymi uran. Pręty sterujące zbudowane są z materiału silnie pochłaniającego neutrony (np. bor czy kadm) i po wprowadzeniu do rdzenia wychwytują nadmiarowe neutrony, zatrzymując łańcuchową reakcję rozszczepienia.

Ważną rolę w reaktorze jądrowym odgrywa tak zwany moderator. Neutrony, które powstają w wyniku reakcji rozszczepienia, mają zbyt dużą energię kinetyczną (są za szybkie), żeby spowodować kolejne rozszczepienia. Dlatego potrzebujemy substancji, która je spowolni do tzw. energii termicznej, wynoszącej ułamki elektronowolta. Taką substancję nazywamy moderatorem. Rolę moderatora pełni najczęściej woda. Jest to tzw. woda lekka, czyli najzwyklejsza woda, lub ciężka, w której znaczącą cześć atomów wodoru stanowi izotop wodoru H-2 zwany deuterem. Początkowo jako moderatora używano również 
grafitu. W reaktorach moderowanych wodą pełni ona dodatkowo rolę chłodziwa. Kiedy dochodzi do sytuacji awaryjnej, pod wpływem rosnącej temperatury woda wyparowuję. Zmniejsza się gęstość ośrodka, neutrony nie są dostatecznie moderowane i reakcja łańcuchowa samoistnie zanika. W przypadku reaktorów moderowanych przez grafit woda pełni rolę tylko i wyłącznie chłodziwa. Gdy istnieje sytuacja awaryjna, woda wyparowuje, natomiast neutrony są wciąż spowalniane. Temperatura rdzenia reaktora rośnie w sposób gwałtowny, mogąc doprowadzić do jego wybuchu.

Nasuwa się na myśl pytanie, gdzie znajduje się niebezpieczeństwo, o którym tak dużo się mówi. Otóż to, co stanowi zagrożenie i niebezpieczeństwo w reaktorze jądrowym, to produkty rozszczepienia, które powstają w paliwie jądrowym. Paliwo jądrowe składa się z prętów paliwowych, w których umieszczone są pastylki paliwowe. Zespół prętów paliwowych składa się na kasety paliwowe, umieszczane w reaktorze.

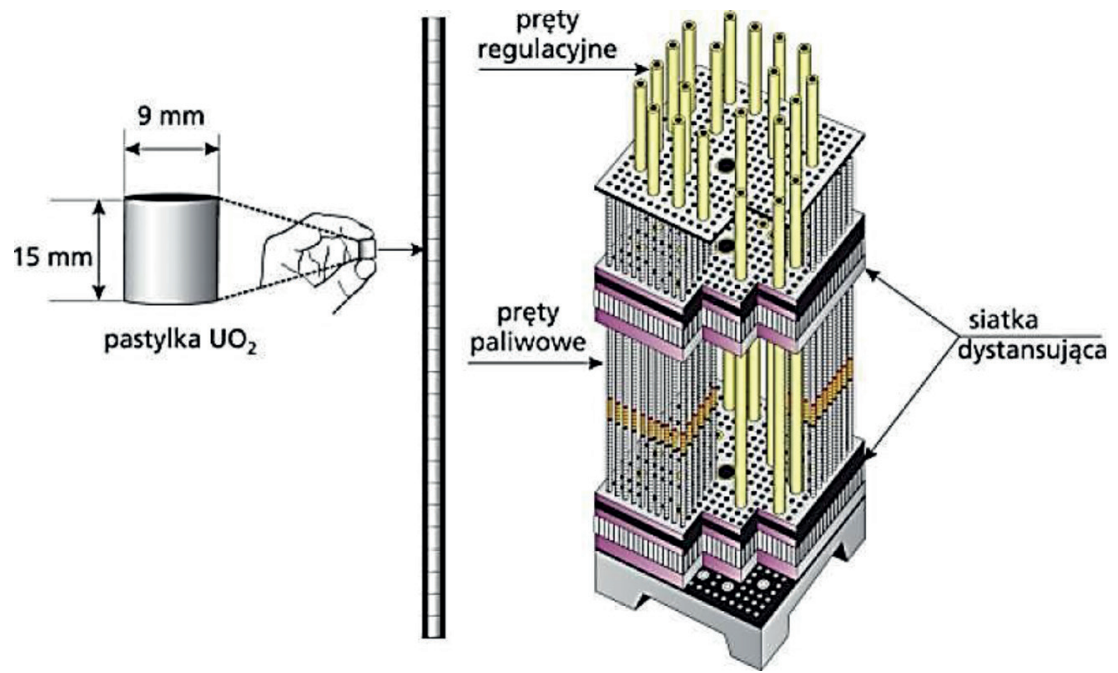

Rysunek 4. Schemat budowy rdzenia reaktora jądrowego. Źródło: nowa.ncbj.edu.pl/sites/default/ files/styles/large/public/field/image/paliwo6_1_1800.jpg?itok=mApCK462 (15.12.2014).

Dlaczego produkty rozszczepienia są takie niebezpieczne? Po pierwsze - wszystkie produkty rozszczepienia są radioaktywne, to znaczy emitują promieniowanie jonizujące o wysokiej energii, przed którym musimy się chronić. Dążymy do tego, aby za wszelką cenę utrzymać je wewnątrz reaktora. Kolejny problem to cie- 
pło emitowane po wyłączeniu reaktora. Promieniowanie jonizujące to energia cieplna. Reaktora jądrowego nie można po prostu wyłączyć. Po jego wyłączeniu mimo że reakcja rozszczepienia już nie zachodzi, to wciąż emitowana jest energia cieplna. Dzieje się tak dlatego, że nadal rozpadają się powstałe w czasie pracy reaktora produkty pierwotnego rozszczepienia. Ponieważ ich okres połowicznego rozpadu, czyli czas, po którym pozostaje połowa jąder danego izotopu, jest różny, jeszcze długo po wyłączeniu reaktora trzeba go chłodzić w celu odprowadzenia ciepła. Nawet po roku od wyłączenia reaktora generowane jest jeszcze ciepło o wartości ok. 0,1 proc. mocy nominalnej. W przypadku francuskiego reaktora EPR, który ma moc cieplną $4500 \mathrm{MW}$, ciepło powyłączeniowe po roku będzie wynosić 4,5 MW - to wciąż jeszcze jest bardzo dużo! Jest to energia pozwalająca na odparowanie $1000 \mathrm{~m}^{3}$ wody w ciągu jednej godziny.

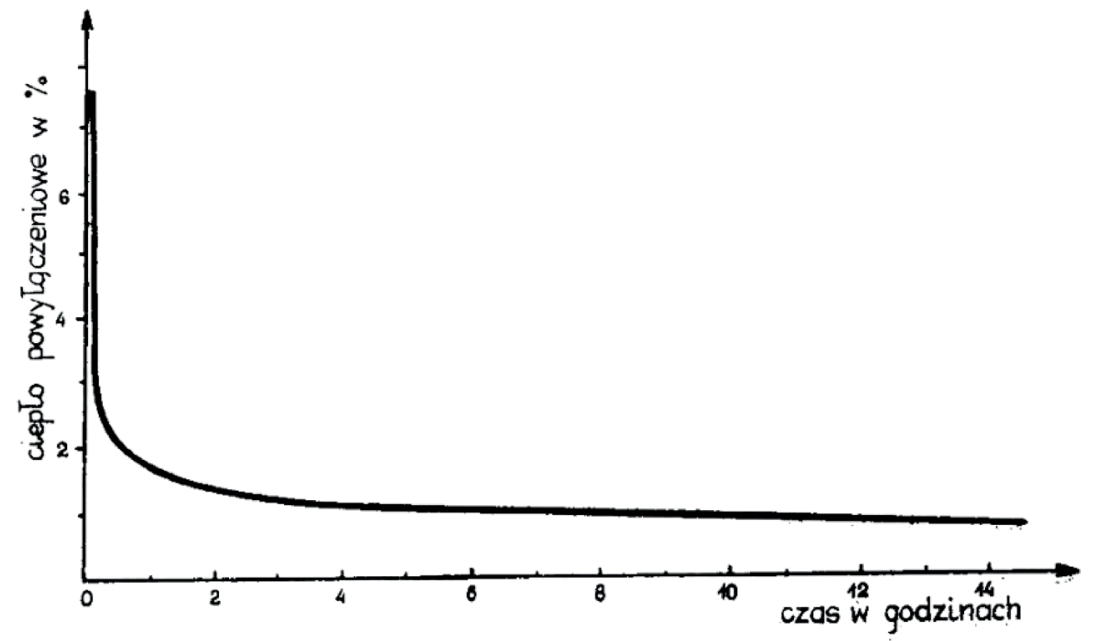

Rysunek 5. Zmniejszanie się ciepła powyłączeniowego z czasem (ciepło powyłączeniowe wyrażone w procentach mocy cieplnej reaktora).

Źródło: www.miroslawmaczka.files.wordpress.com/2011/11/harrisburg2.gif (15.12.2014).

Istnieje wiele typów elektrowni jądrowych, dwa najpopularniejsze to elektrownie z reaktorem wodnym ciśnieniowym $(P W R)^{2}$ i z reaktorem wodnym wrzącym

2 Zob. K. Jeleń, Z. Rau, Energetyka jq̨drowa w Polsce, Warszawa 2012, s. 235. 

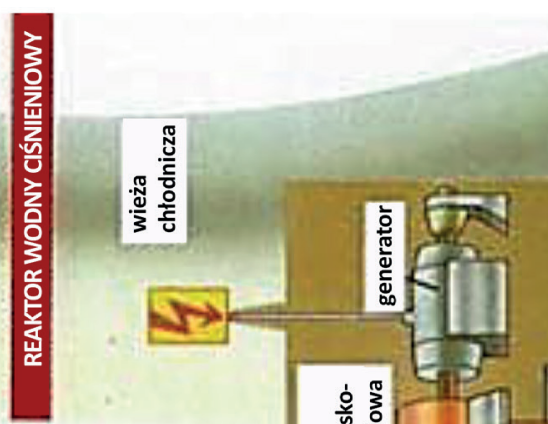

$+2$ 


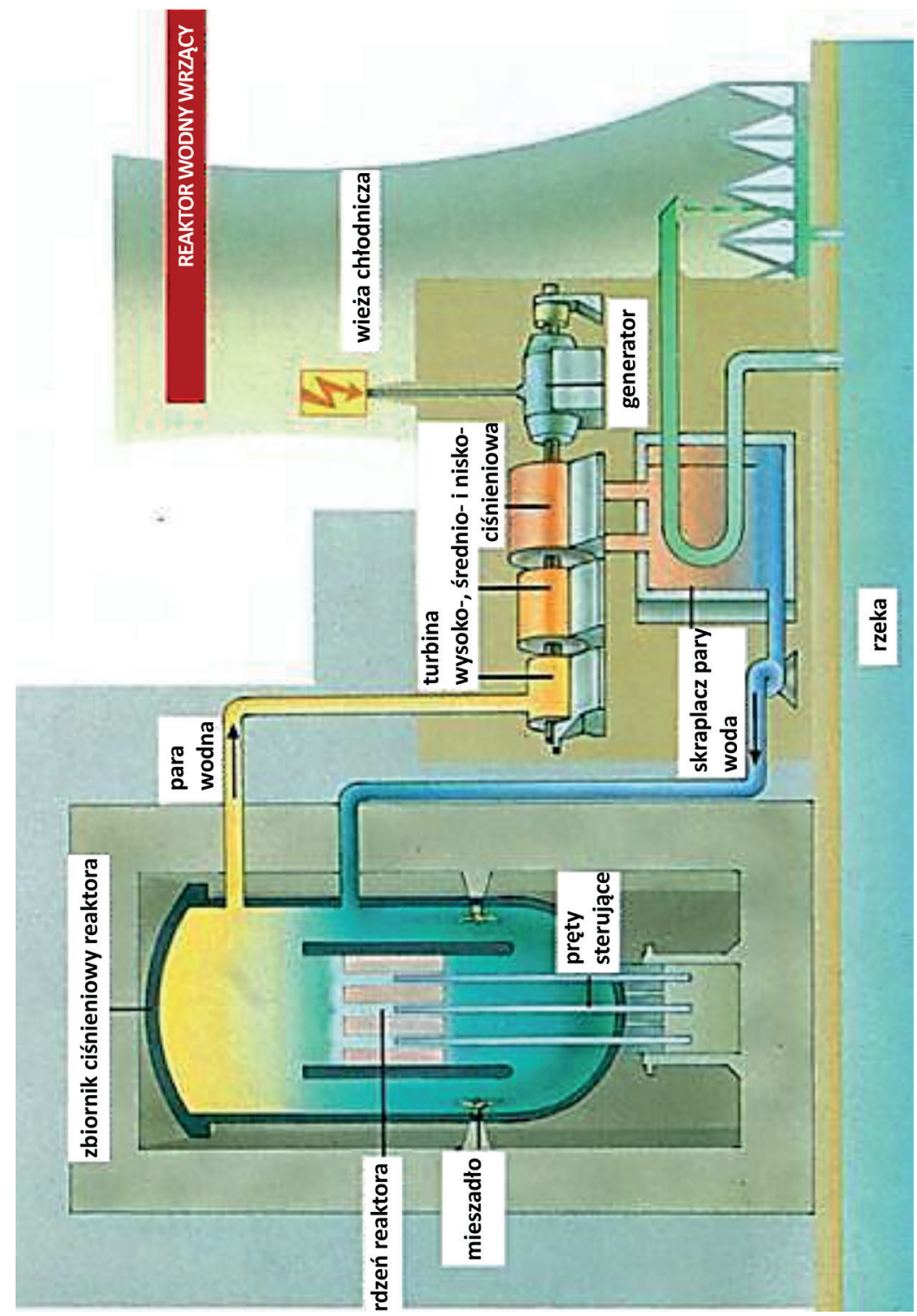

Rysunek 7. Schemat elektrowni jądrowej z reaktorem typu BWR.

Źródło: www.if.pw.edu.pl/ pluta/pl/dyd/mfj/zal03/sobolewski/praca_pliki/image013.jpg (15.12.2014). 
$(B W R)^{3}$. Czym one się różnią? W elektrowni z reaktorem PWR mamy trzy obiegi wody chłodzącej, do których należy: obieg pierwotny, wtórny i obieg wody chłodzącej. Nie prawdą jest, że woda, która wypływa z reaktora, jest skażona. Woda pobierana z rzeki, morza czy jeziora jest używana tylko do chłodzenia pary wodnej, która napędza turbiny energetyczne w drugim obiegu chłodzenia. Zatem z elektrowni wypływa czysta woda, której można się nawet napić. Skażona woda znajduje się jedynie w obiegu pierwotnym. Jest ona skażona, ponieważ opływa bezpośrednio rdzeń reaktora i poddana jest działaniu produktów rozszczepienia. Następnie przepływa do wymiennika ciepła, w którym oddaje ciepło bez wymiany materii, nagrzewając wodę z drugiego obiegu i doprowadzając ją do parowania. W związku z tym, że w wymienniku ciepła nie ma wymiany materii, następuję tylko wymiana energii. Zatem woda w drugim obiegu nie jest skażona. To, co mogłoby powodować zagrożenie, zamknięte jest w specjalnej obudowie bezpieczeństwa i nie wydostaje się na zewnątrz.

Inaczej jest w przypadku elektrowni z reaktorem BWR. W tego typu reaktorze mamy tylko dwa obiegi chłodzenia - obieg pierwotny i obieg wody chłodzącej. Różnica polega na tym, że para wodna powstaje bezpośrednio w zbiorniku reaktora, wychodzi na zewnątrz budynku reaktora i napędza turbiny. Para wodna używana do napędu turbin w reaktorze typu BWR jest skażona. Nie oznacza to jednak, że ta konstrukcja jest niebezpieczna. Niezbędna jest natomiast zaostrzona kontrola radiologiczna, obejmująca również halę turbin. Promieniowanie powoduje również zniszczenia radiacyjne łopat turbin, które trzeba częściej niż w przypadku elektrowni z reaktorem PWR wymieniać. Woda chłodząca parę, podobnie jak w reaktorze PWR, nie styka się z nią fizycznie, co sprawia, że nie ulega skażeniu.

\section{Zasady bezpiecznej eksploatacji reaktorów}

Już od samego początku istnienia elektrowni jądrowych zdawano sobie sprawę z niebezpieczeństwa idącego wraz z wykorzystaniem energii z atomu. Jako podstawowe założenie przyjęto, że ryzyko związane z energetyką jądrową powinno być niższe niż ryzyko związane z innymi metodami wytwarzania energii. Jedyną

3 Zob. tamże, s. 255. 
możliwą drogą rozwoju energetyki jądrowej jest przyjęcie zasad filozofii bezpieczeństwa jądrowego, zapoczątkowane w USA przed 50 laty i stale doskonalonej w krajach zachodnich budujących energetykę jądrową.

Wyszczególniono kilka zasad dotyczących bezpieczeństwa, które muszą być zagwarantowane na etapie projektowania i budowy elektrowni jądrowej ${ }^{4}$. Zasady ogólne to:

1. Instalacja jądrowa musi nadawać się do niezawodnej, stałej i łatwej eksploatacji. Wyznaje się zasadę: „Bezpieczeństwo ważniejsze niż produkcja energii elektrycznej".

2. Zasada głębokiej ochrony, czyli występowanie szeregu poziomów ochrony z wielokrotnymi barierami zabezpieczającymi przed uwalnianiem materiałów radioaktywnych. Należy projektować instalację tak, aby prawdopodobieństwo wystąpienia uszkodzeń w ostateczności prowadzących do awarii było bardzo małe.

3. Rozwiązania techniczne zastosowane w projekcje powinny być uprzednio sprawdzone w pracy lub doświadczalnie.

4. Na wszystkich etapach projektowania i eksploatacji należy uwzględnić problemy wynikające ze współpracy człowieka z maszyną oraz możliwość popełnienia błędu przez człowieka.

5. Projekt musi zapewnić, że narażenie na promieniowanie jonizujące personelu pracującego przy obsłudze instalacji jest tak małe, jak to tylko możliwie jest osiągalne.

6. Zanim projekt zostanie zgłoszony do budowy, należy przeprowadzić pełną analizę bezpieczeństwa elektrowni i jej niezależną weryfikację.

Poniżej ze względu na wagę zostaną omówione zasady głębokiej ochrony.

Celem głębokiej ochrony jest kompensacja możliwych awarii urządzeń i błędów ludzkich. Tworząc system głębokiej ochrony, należy przyjąć brak zaufania do pojedynczych elementów projektu, sposobu konserwacji lub eksploatacji elektrowni jądrowej. Oznacza to, że nie możemy w pełni polegać na danym urządzeniu, licząc na jego bezawaryjną pracę - przyjmujemy, że może ono w każdej chwili ulec awarii. Głęboka ochrona czy tez "zasada ochrony w głąb” zakłada rezerwowanie układów bezpieczeństwa tak, aby w razie uszkodzenia jednego podukładu istniały inne, mogące go zastąpić.

4 A. Strupczewski, Nie bójmy się energetyki jądrowej, Warszawa 2010, s. 89. 
Naturalne cechy bezpieczeństwa elektrowni jądrowej oraz jej układy bezpieczeństwa przeznaczone do powstrzymywania rozwoju awarii są stale doskonalone. Obecnie duży nacisk kładzie się na takie projektowanie reaktorów, aby miały one wbudowane cechy bezpieczeństwa oparte na działaniu zjawisk naturalnych, takich jak siła ciężkości czy prawa konwekcji naturalnej. Przykłady takich środków zostały przedstawione poniżej.

a) Najważniejsza cechą elektrowni jądrowej jest stabilność wewnętrzna reaktorów chłodzonych i moderowanych wodą, dominujących obecnie w energetyce jądrowej na całym świecie. Bardzo ważny jest dostęp do chłodziwa. Część neutronów przy zderzeniu z atomami wodoru ulega pochłanianiu, dlatego ilość wody i paliwa w reaktorze musi być odpowiednio dobrana. Dobór następuje w taki sposób, aby przy normalnej temperaturze pracy zapewniały one najbardziej skuteczne spowolnienie neutronów i wysoce wydajną pracę. Gdy wskutek odparowania wody jej ilość w rdzeniu reaktora zmaleje, neutrony będą gorzej spowalniane i zamiast uderzać w jądra uranu będą wydostawały się na zewnątrz rdzenia, ulegając przy tym pochłanianiu w otaczających go elementach, jak pokazuje Rysunek 8.

A

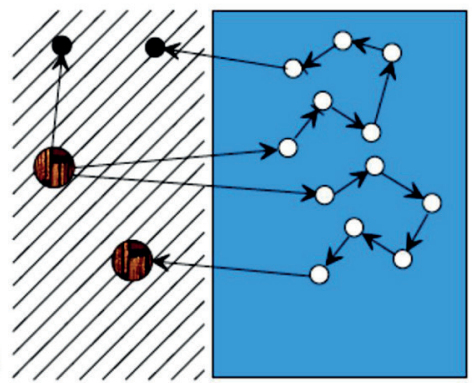

Uran

woda

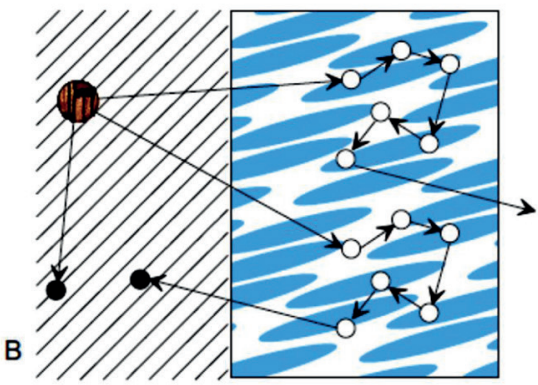

Uran para wodna

Rysunek 8. A - spowolnienie w warunkach normalnej pracy reaktora B - zmiany w spowalnianiu neutronów po częściowym odparowaniu wody w reaktorze PWR i BWR.

Źródło: A. Strupczewski, Nie bójmy się energetyki jqdrowej, Warszawa 2010, s. 91.

Powoduje to zmniejszenie liczby rozszczepień w rdzeniu reaktora i samoczynne wygaszenie łańcuchowej reakcji rozszczepienia. Jest to cecha zapewniająca stabilność pracy reaktorów jądrowych PWR i BWR. 


\section{Układy wyłączające reaktor oparte na działaniu siły ciążenia}

b) Kolejnym zabezpieczeniem opartym na działaniu sił przyrody jest układ wyłączenia reaktora. Składają się na niego specjalne pręty pochłaniające neutrony. W trakcie normalnej pracy reaktora wiszą nad rdzeniem reaktora, utrzymywane przez elektromagnesy (Rysunek 9: A). Gdy nastąpi zanik zasilania elektromagnesów lub układ zabezpieczeń przekaże sygnał o wystąpieniu awarii, napięcie w elektromagnesach zaniknie i pręty samoczynnie, pod wpływem siły ciężkości, spadną do rdzenia reaktora, wyłączając go (Rysunek 9: B).

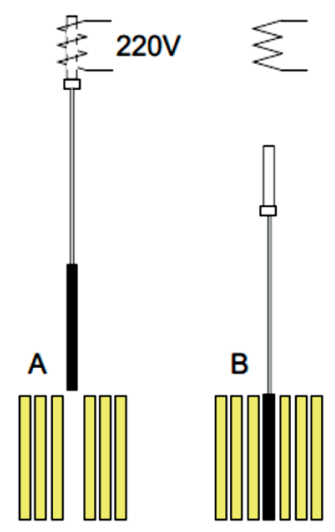

Rysunek 9. Układ wyłączania awaryjnego reaktora. A - normalne położenie prętów podczas pracy reaktora, B - awaryjny zanik napięcia na cewce elektromagnesu - pręty bezpieczeństwa spadają do rdzenia i przerywają reakcję łańcuchową.

Źródło: A. Strupczewski, Nie bójmy się energetyki jqdrowej, Warszawa 2010, s. 91.

c) Zalanie rdzenia wodą w przypadku rozerwania obiegu pierwotnego. W przypadku awarii rozerwania obiegu pierwotnego woda mająca chłodzić reaktor wypływa z rur obiegu i nie trafia do rdzenia reaktora, powodując jego osuszenie. Pozostawienie prętów paliwowych bez chłodzenia spowoduje wzrost ich temperatury, a w konsekwencji doprowadzi do stopienia paliwa. Dlatego po wyłączeniu reaktora pierwszym zadaniem układów bezpieczeństwa jest wtryśnięcie do reaktora wody, tak aby rdzeń pozostał pod powierzchnią wody. Obecnie stosowane w reaktorach układy awaryjnego chłodzenia (UACR) opierają się na aktywnym i biernym działaniu. Układy aktywne potrzebują do swojego działa- 
nia napięcia elektrycznego, natomiast układy bierne nie wymagają ingerencji człowieka i działają samoczynnie bez konieczności ich zasilania. Przykład układu pasywnego opartego na działaniu różnicy ciśnień prezentuje Rysunek 10. Zbiorniki kumulujące wodę pod ciśnieniem $\mathrm{P}_{1}$ są odcięte od rdzenia zaworami zwrotnymi, które pozostają tak długo zamknięte, jak długo ciśnienie $P_{0} w$ rdzeniu jest wyższe od ciśnienia $P_{1}$. Kiedy podczas awarii ciśnienie $w$ obiegu pierwotnym spadnie, zawory otworzą się i rdzeń reaktora zostanie zalany wodą. Układy aktywne posiadają trzy lub cztery równoległe podukłady ze zbiornikami chłodziwa, pompami i zaworami. Są tak zaprojektowane aby tylko jeden z nich wystarczał do zalania rdzenia wodą i skutecznego chłodzenia.

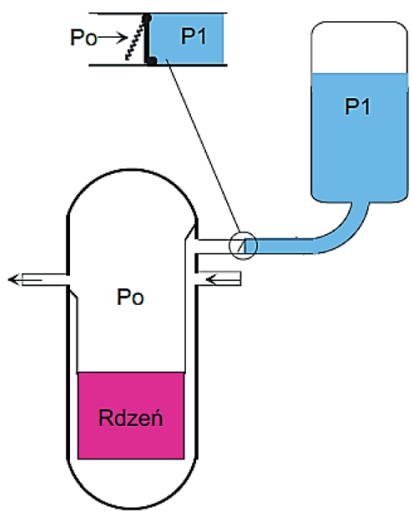

Rysunek 10. Bierny Układ Awaryjnego Chłodzenia Rdzenia, BUACR.

Źródło: A. Strupczewski, Nie bójmy się energetyki jqqdrowej, Warszawa 2010, s. 92.

d) Różnorodność układów. Istnienie dwóch lub więcej systemów zapewniających wzajemne rezerwowanie (czyli jeżeli jeden z elementów zawiedzie, mamy kolejny), jest zabezpieczeniem przed awarią pojedynczego elementu, ale nie daje gwarancji, że cały układ nie zawiedzie z powodu wspólnej przyczyny. Aby temu zapobiec, podukłady wzajemnie rezerwujących się systemów są wykonane z różnych elementów, tak aby jedna przyczyna awarii nie spowodowała jednoczesnej utraty wszystkich systemów. Przykładem takiego układu wyłączania reaktora jest układ „dwa z trzech” pokazany na Rysunku 11. Aby wyłączenie reaktora nie następowało przy każdym uszkodzeniu miernika temperatury, przyjęto, że mierzy się sygnały z trzech mierników. Jeżeli dwa z nich pokażą przekroczenie temperatury, układ zabezpieczeń wyłącza reaktor. Aby jednak chronić 
się przed możliwością niepoprawnego działania czujników temperatury, dodatkowo podłączony jest układ pomiaru ciśnienia. Działa on na tej samej zasadzie.

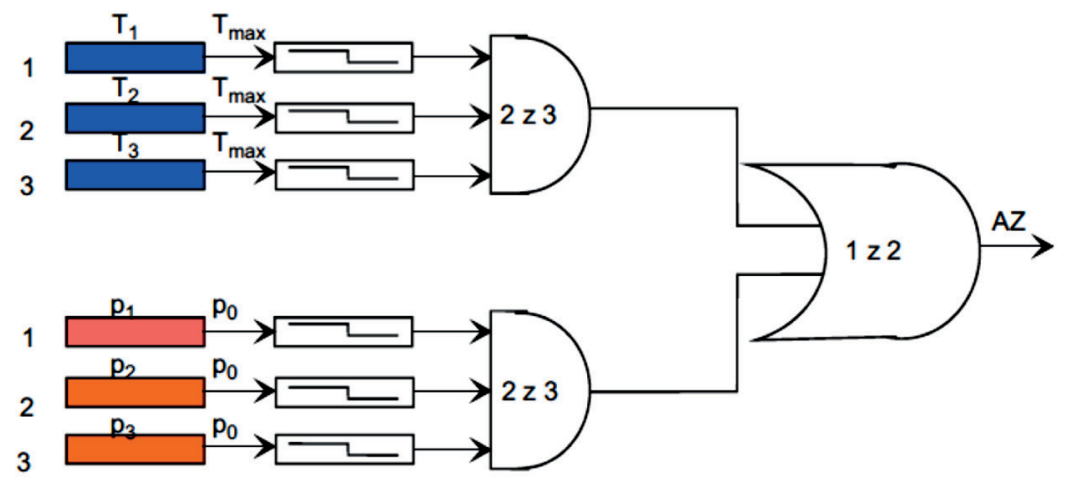

Rysunek 11. Układ zabezpieczeń reaktora jest zbudowany na zasadzie redundancji i głosowania 2/3 oraz różnorodności polegającej na tym, że zarówno sygnały ciśnienia $\mathrm{P}$, jak i temperatury T powodują wytworzenie sygnału awaryjnego wyłączenia reaktora. $T_{1}, T_{2}, T_{3}-$ temperatury chłodziwa; $P_{1}, P_{2}$, $\mathrm{P}_{3}$-ciśnienie w stabilizatorze; $T_{\text {max }}, P_{0}$ - wartości progowe; $A Z$ - sygnał awaryjnego wyłączenia reaktora. Źródło: A. Strupczewski, Nie bójmy się energetyki jq̨drowej, Warszawa 2010, s. 94.

e) Rozdzielenie przestrzenne układów

Układy bezpieczeństwa są rozdzielone przestrzennie i fizycznie od siebie, tak aby żadna katastrofa nie spowodowała utraty zasilania. W nowoczesnych elektrowniach każdy z czterech podsystemów układów bezpieczeństwa znajduje się w innej części budynku reaktora.

Nawet rezerwowanie i różnorodność elementów bezpieczeństwa nie wystarczyłaby, gdyby elementy te nie były odporne na wstrząsy sejsmiczne, temperaturę, ciśnienie, możliwość wystąpienia pożaru i wilgotność. Dlatego podczas projektowania układów ważnych dla bezpieczeństwa elektrowni jądrowej analizuje się możliwość wystąpienia poszczególnych czynników i rozmieszcza się elementy oraz zabezpiecza w taki sposób, aby w miarę możliwości zapewnić im bezawaryjne działanie.

Analizy odporności obudowy bezpieczeństwa w nowoczesnych elektrowni jądrowych potwierdziły, że z jednej strony mogą one wytrzymać uderzenie samolotu bez utraty szczelności, a z drugiej strony, nawet w razie poważnej awarii ze stopieniem rdzenia, powstrzymują skutecznie uwolnione produkty rozszczepienia. 


\section{Organizacja bezpieczeństwa jądrowego}

System organizacji bezpieczeństwa jądrowego ${ }^{5}$ oparty jest na odpowiednich przepisach. Zbudowany jest on na trzech płaszczyznach:

- na odpowiedzialności technicznej spoczywającej na operatorze instalacji;

- na kontroli sprawowanej przez władze, polegającej na egzekwowaniu pełnej realizacji obowiązków wynikających z odpowiedzialności technicznej, zgodnie z wymogami ustaw i przepisów;

- na kontroli instytucjonalnej oraz publicznej, której zadaniem jest zapewnienie przejrzystości w zakresie bezpieczeństwa.

Prawo jądrowe opiera się na bardzo rygorystycznych zasadach, obejmuje instytucje tak zwanych podstawowych instalacji jądrowych, tryby i procedury udzielania zezwoleń, kodeksy i zasady techniczne, a także podstawowe zasady bezpieczeństwa. Mając na uwadze zagadnienia techniczne, władze wyznaczają ogólne cele w zakresie bezpieczeństwa. Natomiast obowiązkiem operatora jest zaproponować środki pozwalające na ich osiągnięcie. Operatorzy jądrowi posiadają własne służby kontrolne i zobowiązani są do publikowania corocznego raportu o bezpieczeństwie.

\section{Kontrola bezpieczeństwa jądrowego i ochrony radiologicznej}

Do kontrolowania bezpieczeństwa jądrowego 6 i ochrony radiologicznej w Europie 25 marca 1957 roku została powołana przez traktat EURATOM Europejska Wspólnota Energii Atomowej.

Na szczeblu międzynarodowym najważniejszymi instytucjami są:

- MAEA (Międzynarodowa Agencja Energii Atomowej) - jest wyspecjalizowaną jednostką w ramach organizacji ONZ i działa jako międzynarodowe forum współpracy naukowo-technicznej, zajmuje się wszystkimi aspektami energetyki jądrowej;

- AEN (Agencja Energii Nuklearnej) - tworzą ją przedstawiciele władz dozorowych i jednostek badawczo-rozwojowych;

\footnotetext{
Zob. Areva, Wszystko o energetyce jadrowej. Od atomu A do cyrkonu Zr, Paryż 2008, s. 130.

Zob. tamże, s. 133.
} 
- ICRP (Międzynarodowa Komisja Ochrony Radiologicznej) - utworzona, aby wydawać zalecenia w zakresie ochrony radiologicznej, stanowiące podstawę dla przepisów międzynarodowych i krajowych;

- UNSCEAR (Komitet Naukowy Narodów Zjednoczonych ds. Skutków Promieniowania Atomowego) - prowadzi prace naukowo-badawcze nad skutkami zdrowotnymi promieniowania jonizującego.

\section{Podsumowanie}

W Polsce planowana jest budowa pierwszej elektrowni jądrowej. Niestety, technologia ta wciąż budzi obawy i nie ma czemu się dziwić - podobnie było np. z zaćmieniem Słońca, minęło wiele lat zanim ludzie przestali się obawiać tego zjawiska. Energetyka jądrowa ma już ponad 60 lat, ponad 100 lat minęło od odkrycia promieniotwórczości, a wciąż zastosowanie promieniowania jonizującego w przemyśle czy medycynie oraz pokojowe wykorzystanie energii jądrowej budzi strach i złe emocje. Mam nadzieję, że informacje zawarte w artykule pozwoliły choć w małym stopniu zrozumieć zasadę funkcjonowania oraz zabezpieczenia i kontrolę elektrowni jądrowej, jak również zmniejszyły obawy związane z jej działaniem. Być może za 50, 100 czy 200 lat technologie jądrowe będą czymś tak naturalnym, jak obecnie energia elektryczna, bez której nie potrafimy sobie wyobrazić codziennego życia. Oswajanie społeczeństwa z technologią jądrową jest niestety procesem powolnym i żmudnym i wymaga dużego zaangażowania w popularyzację nowych technologii.

\section{Bibliografia}

Areva, Wszystko o energetyce jqdrowej. Od atomu A do cyrkonu Zr, Paryż 2008.

Jeleń K., Rau Z., Energetyka jqdrowa w Polsce, Warszawa 2012.

Koszuk Ł., Albert Einstein i równanie E= mc2, „Forum Atomowe” 2 (2013) www.forumatomowe.org/pdf/forum_atomowe_numer_2_2013.pdf (15.12.2014).

Strupczewski A., Nie bójmy się energetyki jądrowej, Warszawa 2010. 